\title{
Effects of Intracisternal Dexmedetomidine on Cerebral Neuronal Cells in Rat: A Preliminary Study
}

\author{
Ratlarda Intrasisternal Deksmedetomidinin Serebral Nöron Hïcreleri \\ Üzerine Etkisi: Bir Ön Çalışma
}

Emine Arzu KOSE ${ }^{1}$, Bulent BAKAR ${ }^{2}$, Omur KASIMCAN², Pergin ATILLA ${ }^{3}$, Kamer KILINC ${ }^{4}$, Sevda MUFTUOGLU ${ }^{3}$, Alpaslan APAN ${ }^{1}$

${ }_{1}^{1}$ Kirikkale University, Faculty of Medicine, Department of Anesthesiology and Reanimation, Kirikkale, Turkey

${ }^{2}$ Kirikkale University, Faculty of Medicine, Department of Neurosurgery, Kirikkale, Turkey

${ }^{3}$ Hacettepe University, Faculty of Medicine, Department of Histology and Embryology, Ankara, Turkey

${ }^{4}$ Hacettepe University, Faculty of Medicine, Department of Biochemistry, Ankara, Turkey

Correspondence address: Emine Arzu KOSE / E-mail: arzuhct@hotmail.com

\begin{abstract}
AIM: The aim was to investigate whether dexmedetomidine had a toxic effect on cerebral neurons when it was administered centrally into the cerebrospinal fluid by the intracisternal route.

MATERIAL and METHODS: Eighteen rats were anesthetized and the right femoral artery was cannulated. Mean arterial pressures, heart rates, arterial carbon dioxide tension, arterial oxygen tension, and blood $\mathrm{pH}$ were recorded. When the free cerebrospinal fluid flow was seen, $0.1 \mathrm{ml}$ normal saline (Group SIC, $\mathrm{n}=6$ ) or $9 \mu \mathrm{g} / \mathrm{kg}$ diluted dexmedetomidine in $0.1 \mathrm{ml}$ volume (Group DIC, $\mathrm{n}=6$ ) was administered into the cisterna magna of rats. After 24 hours, the whole body blood was collected for measurement of plasma lipid peroxidation (LPO) levels. The hippocampal formations used for histopathological examination and measurement of tissue LPO levels.

RESULTS: There was a statistically significant difference between the DIC/SIC groups and DIC/CONTROL groups regarding the brain LPO levels $(p=0.002, p<0.001$, respectively). Plasma LPO levels were statistically different between the CONTROL/DIC groups, CONTROL/SIC groups, DIC/ $\mathrm{SIC}$ groups $(\mathrm{p}=0.002, \mathrm{p}=0.047, \mathrm{p}=0.025$, respectively), The picnotic neuron counts were different between the CONTROL/SIC groups, CONTROL/ DIC groups, DIC/SIC groups ( $\mathrm{p}<0.001, \mathrm{p}=0.001, \mathrm{p}=0.024$, respectively).

CONCLUSION: In conclusion, dexmedetomidine had a toxic effect on cerebral neurons when it was administered centrally into the cerebrospinal fluid by the intracisternal route.
\end{abstract}

KEYWORDS: Dexmedetomidine, Intracisternal, Intrathecal, Hippocampus, Brain, Cerebral neuron

öz

AMAÇ: Intrasisternal olarak serebrospinal sıvı içine santral yolla verilen deksmedetomidinin serebral nöronlar üzerinde toksik etkisinin olup olmadığını araştırmak amaçlandı.

YÖNTEM ve GEREÇLER: On sekiz sıçana anestezi verildikten sonra sağ femoral arterleri kanülize edildi. Ortalama arter basınçları, kalp hızları, arteriyal karbon dioksit basınçları, arteriyal oksijen basınçları, kan pH değerleri kaydedildi. Serbest serebrospinal sıvı akışı görüldükten sonra ratların sisterna magnaları içine $0,1 \mathrm{ml}$ serum fizyolojik (Grup SIC, $\mathrm{n=6}$ ) veya 0,1 ml volüm içinde $9 \mu \mathrm{g} / \mathrm{kg}$ sulandırılmış deksmedetomidin (Grup DIC, $n=6$ ) verildi. Yirmi dört saat sonra lipid peroksidasyon (LPO) seviyesi ölçümleri için tüm vücut kanı toplandı. Histopatolojik inceleme ve doku LPO seviyesi ölçümleri için hipokampüs kullanıldı.

BULGULAR: Beyin dokusu LPO seviyeleri yönünden DIC/SIC ve DIC/CONTROL grupları arasında istatistiksel belirgin farklılık vardı (sırasıyla, $\mathrm{p}=0.002, \mathrm{p}<0.001)$. Plazma LPO seviyeleri CONTROL/DIC, CONTROL/SIC, DIC/SIC grupları arasında istatistiksel olarak farklıydı (sırasıyla, $p=0,002$, $p=0,047, p=0,025)$. Piknotik nöron sayıları CONTROL/SIC, CONTROL/ DIC, DIC/SIC grupları arasında istatiksel olarak farklıydı (sırasıyla, $p<0,001$, $p=0,001, p=0,024)$.

SONUÇ: Sonuç olarak, intrasisternal olarak serebrospinal sıvı içine santral yolla verilen deksmedetomidinin serebral nöronlar üzerine toksik etkisi olduğu görüldü.

ANAHTAR SÖZCÜKLER: Deksmedetomidin, İntrasisternal, İntratekal, Hipokampüs, Beyin, Serebral nöron 


\section{INTRODUCTION}

Dexmedetomidine is a short acting, highly lipid-soluble, selective $a_{2}$ - adrenergic agonist agent which has potent sedative properties (3). It has been demonstrated that dexmedetomidine produces antinociception in systemic $(23,28)$, intrathecal $(2,29)$ or epidural administration $(1)$. It has been reported that the addition of dexmedetomidine to local anesthetic solution in intravenous regional anesthesia improved the quality of anesthesia and decreased the analgesic requirements $(5,20)$. There is evidence that systemic administration of dexmedetomidine may partially prevent neuronal damage in some models of brain ischemia and this neuroprotective effect is mediated by the activation of the $a_{2}$-adrenergic receptors $(8,9,15-17)$. On the other hand, it has been shown by Konakci et al. that dexmedetomidine produced moderate or severe demyelinization of myelin sheats in the white matter of spinal cord in rabbit, when it is administered by the epidural route (14), and this effect has been explained by the agent's vasoconstrictive effect on medullar spinal vessels (10). It is known that topical application of dexmedetomidine had vasoconstrictor effects both on cerebral pial arterial and venous vessels (11). Additionally, it has been reported in an experimental study that centrally administered dexmedetomidine reduced cerebral blood flow during normoxia and prevented adequate oxygen delivery during hypoxia (19).

Establishing the safety of neuroaxial drugs is very important before these drugs are given to humans. Despite extensive use in animal experimentation, there has been no study in the medical literature about the effects of this highly liposoluble and selective $a_{2}$-adrenergic agonist anesthetic agent on cerebral neurons when administered intrathecally into the cerebrospinal fluid. The purpose of this prospective, randomized, double-blind, controlled study was to investigate whether dexmedetomidine had a toxic effect on cerebral neurons when it was administered centrally into the cerebrospinal fluid by the intracisternal route.

\section{MATERIAL and METHODS}

This experiment was performed in accordance with the guidelines for the use of laboratory animal subjects in research set by the Ethical Committee of Kirikkale University. Eighteen male Wistar rats of 250-300 gram weight were used. The rats were placed in a temperature $\left(21 \pm 2{ }^{\circ} \mathrm{C}\right)$ and humidity $(60 \pm$ $5 \%$ ) controlled room for one week before the experiment, a $12 \mathrm{~h}$ light / $12 \mathrm{~h}$ dark cycle was maintained, and was allowed free access to food and water before and after surgery. The animals were divided into three groups randomly which were named as follows:

DIC $\left(9 \mu \mathrm{g} / \mathrm{kg}\right.$ dexmedetomidine (Precedex ${ }^{\oplus}$; Hospira, Inc. Lake Forest, IL 60045, USA) which was diluted with $0.9 \%$ saline administered in a volume of $0.1 \mathrm{ml}$ by the intracisternal route) $(n: 6)$,

SIC $(0.9 \% \mathrm{NaCl}$ in a volume of $0.1 \mathrm{ml}$ administered by the intracisternal route $(n: 6)$,
CONTROL (no agent was administered by the intracisternal route) (n: 6).

Anesthesia was performed with intramuscular administration of $40 \mathrm{mg} / \mathrm{kg}$ ketamine $\mathrm{HCl}$ (Ketalar; ; Pfizer Inc, USA) and $5 \mathrm{mg}$ / kg xylazine $\mathrm{HCl}$ (Rompun \% 2; Bayer HealthCare AG, Germany). Rats were kept normothermic with thermoregulatory heating unit (Harvard Apparatus) connected to the rectal probe. The right femoral artery was cannulated for continuous blood pressure monitoring (CardioCap II, Datex, Finland), and to obtain arterial blood samples. Mean arterial pressures (MAP) and heart rates (HR) were recorded during the study. Arterial blood samples were obtained at 0, 5, 15, 30 and 60 minutes to evaluate arterial carbon dioxide tension $\left(\mathrm{PaCO}_{2}\right)$, arterial oxygen tension $\left(\mathrm{PaO}_{2}\right)$, and blood $\mathrm{pH}$ (ABL5, Radiometer, Denmark). When the free cerebrospinal fluid flow was seen, $0.1 \mathrm{ml}$ normal saline (Group SIC, $\mathrm{n}=6$ ) or $9 \mu \mathrm{g} / \mathrm{kg}$ diluted dexmedetomidine in $0.1 \mathrm{ml}$ volume (Group DIC, $\mathrm{n}=6$ ) was administered within one minute from the posterior craniocervical junction of rats using a $26 \mathrm{G}$ needle. During the recovery period, catheters were removed. Then the animals were returned to their home cages. Twenty four hours later, all animals were re-anaesthetized with intramuscular $40 \mathrm{mg} /$ $\mathrm{kg}$ ketamine $\mathrm{HCl}$ and $5 \mathrm{mg} / \mathrm{kg}$ xylazine $\mathrm{HCl}$. For sacrification, the whole body blood was collected from the vena cava inferior, and then the rats were decapitated. The brains were immediately harvested for future biochemical and histopathological examinations. All rat brains were divided into two hemispheres with a cut from sulcus centralis and then the hippocampal formations of the right hemisphere were dissected and stored in 10\% buffered formaldehyde solution at room temperature for future histopathological examination. For biochemical examination, the remaining part of the right hemisphere and the plasma of the collected whole body blood were immediately stored at $-30^{\circ} \mathrm{C}$ in dry air.

\section{Biochemical Analysis:}

Biochemical determinations were carried out by a biochemist blinded to the animal groups and test materials. Frozen tissue samples were weighted and homogenized in 1:10 (w:v) potassium phosphate buffer $(50 \mathrm{mM}, \mathrm{pH}: 7.4)$ by using a dounce homogenizer. Thiobarbituric acid reactive substances (TBARS) were measured as an index of LPO by the method of Mihara et al $(21,22)$. Tissue levels of lipid peroxides (as TBARS) were calculated as nanomole per gram wet tissue. Serum levels of lipid peroxides were determined by tiobarbituric acid (TBA) assay as described by Wade and van Rij, and calculated as micromole per liter (27).

\section{Histopathological Analysis:}

For histological examination, all tissue samples were fixed at $10 \%$ buffered formaldehyde and processed according to routine light microscopic tissue processing technique. Serial coronal sections of $5 \mu \mathrm{m}$ at the level of the hippocampus formation stained with haematoxylene-eosin were examined and photographed by an Olympus BH-2 microscope. Three 
random regions were examined at $X 200$ magnification and the number of picnotic neurons in three areas per section of hippocampal dentate gyrus (DG) region were identified and counted on the basis of the presence of picnotic nuclei and shrunken cytoplasm. Then the number of the picnotic neuronal cells was calculated as an average per rat. Each of the three sections was evaluated independently by two histologists blinded to the groups. The results of the two histologists were compared and an average was determined.

\section{Statistical Analysis:}

Data were analyzed using the SPSS 11.5 (SPSS Inc. Software, Chicago, Illinois, USA) statistical software. All data were presented as mean \pm SD. Because tissue LPO levels, plasma LPO levels, histopathological data and the data of physiological parameters were normally distributed and the variations were homogenous among all groups, analyzed by using one-way analysis of variance (ANOVA) and with Tukey test as to compare the groups, and determine the differences among groups, respectively. The repeated measures of physiological parameters within different times were analyzed using general linear model analysis of variance for repeated measures. $P<0.05$ was considered statistically significant.

\section{RESULTS}

\section{Physiological Parameters:}

Blood gas tensions, MAP, $\mathrm{pH}$ and rectal temperatures were similar among all groups at all times. The repeated measures of physiological parameters within different times were also similar in all groups (Table I).

\section{Biochemical Analysis:}

There was a statistically significant difference among all groups regarding the brain LPO levels $(F=14,889, p<0.001)$. When posthoc comparisons were made by using Tukey Multiple Comparison Test, statistically differences were observed between the DIC/SIC groups and the DIC/CONTROL groups ( $p=0.002$ and $p<0.001$, respectively) (Figure 1 ).

There was also statistically significant difference among all groups regarding the plasma LPO levels $(F=9,386, p=0.002)$. The mean plasma LPO levels were statistically different between the CONTROL/DIC groups and CONTROL/SIC groups $(p=0.002$ and $p=0.047$, respectively). Additionally, the mean plasma levels of the DIC group was statistically different from the SIC group ( $\mathrm{p}=0.025$ ) (Figure 2).

\section{Histopathological Analysis:}

There was a statistically significant difference among all groups regarding the picnotic neuronal cell counts in the hippocampus $(\mathrm{F}=28.181, \mathrm{p}<0.001)$. When posthoc comparisons were made by using Tukey Multiple Comparison Test, statistically differences were observed between the CONTROL/DIC groups and the CONTROL/SIC groups $(p<0.001$, and $p=0.001$, respectively). Beside this, there was a statistically significant difference between the DIC group and the SIC group ( $p=0.024)$ (Figure 3 ).
Table I: Physiological Parameters in the Study Groups

\begin{tabular}{|c|c|c|c|c|c|c|}
\hline $\begin{array}{c}\text { Group } \\
\text { (n) }\end{array}$ & $\begin{array}{c}\text { MAP } \\
(\mathrm{mmHg})\end{array}$ & $\begin{array}{c}\text { HR } \\
\text { (beat/min) }\end{array}$ & $\begin{array}{l}\mathrm{PaCO}^{2} \\
(\mathrm{mmHg})\end{array}$ & $\begin{array}{c}\mathrm{PaO}^{2} \\
(\mathrm{mmHg})\end{array}$ & $\mathrm{pH}$ & $\begin{array}{l}\text { Rectal } \\
\text { Temp. } \\
\left({ }^{\circ} \mathrm{C}\right)\end{array}$ \\
\hline \multicolumn{7}{|l|}{ DIC (6) } \\
\hline T0 & $107 \pm 3$ & $387 \pm 13$ & $45.0 \pm 4.4$ & $144.0 \pm 11.2$ & $7.36 \pm 0.03$ & $37.2 \pm 0.4$ \\
\hline T5 & $98 \pm 5$ & $376 \pm 9$ & $44.8 \pm 3.5$ & $147.0 \pm 6.3$ & $7.38 \pm 0.01$ & $37.3 \pm 0.3$ \\
\hline T15 & $110 \pm 7$ & $380 \pm 11$ & $41.5 \pm 2.3$ & $139.6 \pm 5.6$ & $7.41 \pm 0.04$ & $37.1 \pm 0.2$ \\
\hline T30 & $108 \pm 6$ & $395 \pm 7$ & $41.9 \pm 2.5$ & $142.0 \pm 10.0$ & $7.40 \pm 0.02$ & $37.5 \pm 0.5$ \\
\hline T 60 & $104 \pm 7$ & $389 \pm 8$ & $42.7 \pm 5.5$ & $138.0 \pm 7.2$ & $7.37 \pm 0.02$ & $37.1 \pm 0.3$ \\
\hline \multicolumn{7}{|l|}{$\operatorname{SIC}(6)$} \\
\hline T0 & $109 \pm 5$ & $383 \pm 10$ & $40.0 \pm 5.3$ & $145.0 \pm 12.1$ & $7.41 \pm 0.03$ & $37.1 \pm 0.2$ \\
\hline T5 & $105 \pm 6$ & $388 \pm 9$ & $44.6 \pm 3.2$ & $147.2 \pm 11.7$ & $7.39 \pm 0.01$ & $37.4 \pm 0.3$ \\
\hline T15 & $97 \pm 6$ & $391 \pm 7$ & $41.8 \pm 2.5$ & $138.5 \pm 7.1$ & $7.40 \pm 0.01$ & $37.1 \pm 0.1$ \\
\hline T30 & $102 \pm 7$ & $387 \pm 12$ & $43.7 \pm 4.3$ & $141.5 \pm 8.3$ & $7.43 \pm 0.04$ & $37.3 \pm 0.4$ \\
\hline T 60 & $99 \pm 4$ & $394 \pm 11$ & $40.7 \pm 1.2$ & $139.8 \pm 7.2$ & $7.41 \pm 0.01$ & $37.0 \pm 0.1$ \\
\hline \multicolumn{7}{|c|}{ CONTROL(6) } \\
\hline T0 & $109 \pm 7$ & $386 \pm 7$ & $43.0 \pm 5.3$ & $145.3 \pm 11.4$ & $7.41 \pm 0.02$ & $37.4 \pm 0.3$ \\
\hline T5 & $103 \pm 8$ & $391 \pm 12$ & $42.6 \pm 7.6$ & $142.6 \pm 4.9$ & $7.39 \pm 0.01$ & $37.3 \pm 0.2$ \\
\hline T15 & $98 \pm 5$ & $387 \pm 6$ & $44.1 \pm 4.2$ & $141 \pm 10.0$ & $7.43 \pm 0.04$ & $37.5 \pm 0.4$ \\
\hline T30 & $105 \pm 6$ & $380 \pm 5$ & $43.7 \pm 5.1$ & $139.4 \pm 3.7$ & $7.37 \pm 0.02$ & $37.1 \pm 0.2$ \\
\hline T 60 & $102 \pm 7$ & $393 \pm 10$ & $44.0 \pm 3.7$ & $137.8 \pm 6.9$ & $7.38 \pm 0.03$ & $37.2 \pm 0.1$ \\
\hline
\end{tabular}

Data are expressed as mean $\pm \mathrm{SD}$; 1 Fnumber of animal; $\mathrm{T} 0, \mathrm{~T} 5, \mathrm{~T} 15, \mathrm{~T} 30$ and $\mathrm{T} 60=0,5^{\text {th }}$, $15^{\text {th }}, 30^{\text {th }}$ and $60^{\text {th }}$ minutes of the study, MAP=mean arterial blood pressure; HR=heart rate; $\mathrm{PaCO}^{2}=$ arterial carbon dioxide pressure; $\mathrm{PaO}=$ arterinl oxygen pressure; Temp=temperature; $\mathrm{DIC}=$ dexmede tomidine intracisternal; SIC=saline intracisternal.

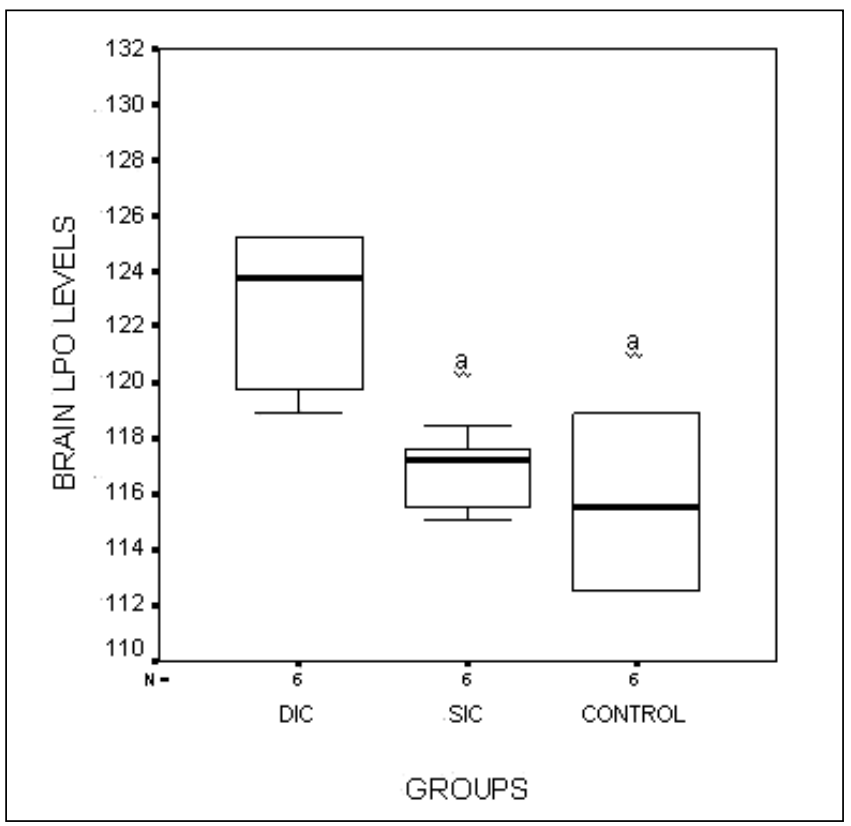

Figure 1: The mean values of the lipid peroxidation levels of the brain tissue of the groups. LPO = lipid peroxidation; DIC = dexmedetomidine intracisternal; SIC = saline intracisternal, $\mathbf{a}=$ significant difference from DIC group. 
Histopathological examination of the DIC group demonstrated severe edema both at the neuropil and perivascular area. There were significant capillary stasis and perivascular edema,

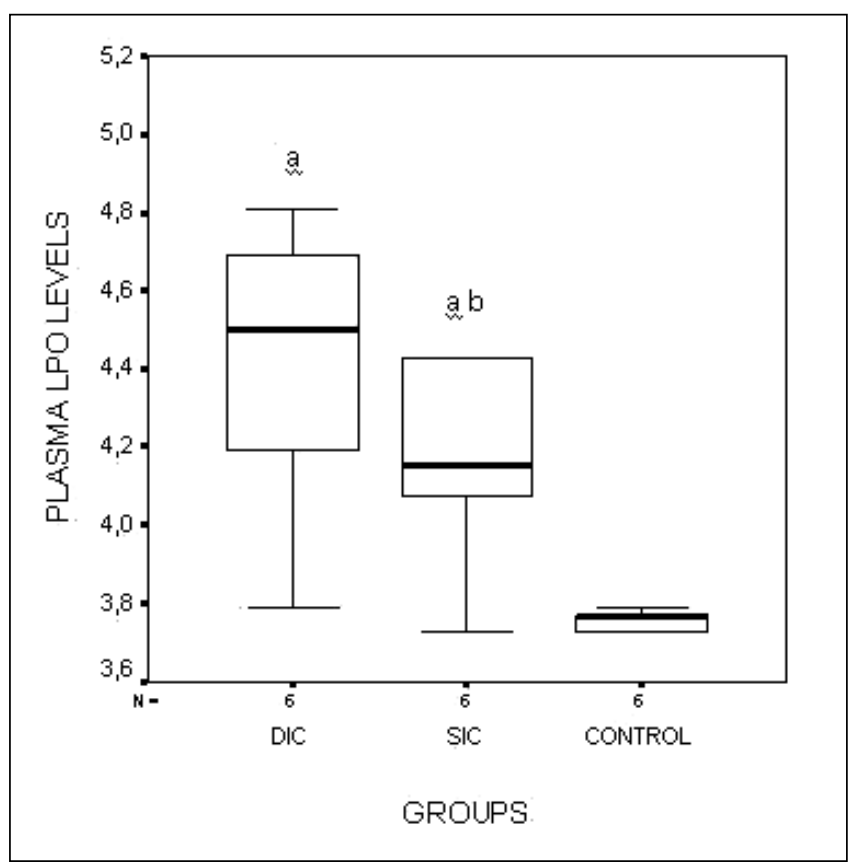

Figure 2: The mean values of the plasma lipid peroxidation levels of the groups. $\mathbf{L P O}=$ lipid peroxidation; $\mathbf{D I C}=$ dexmedetomidine intracisternal, $\mathbf{S I C}=$ saline intracisternal, $\mathbf{a}=$ significant difference from the CONTROL group; $\mathbf{b}=$ significant difference from the DIC group.

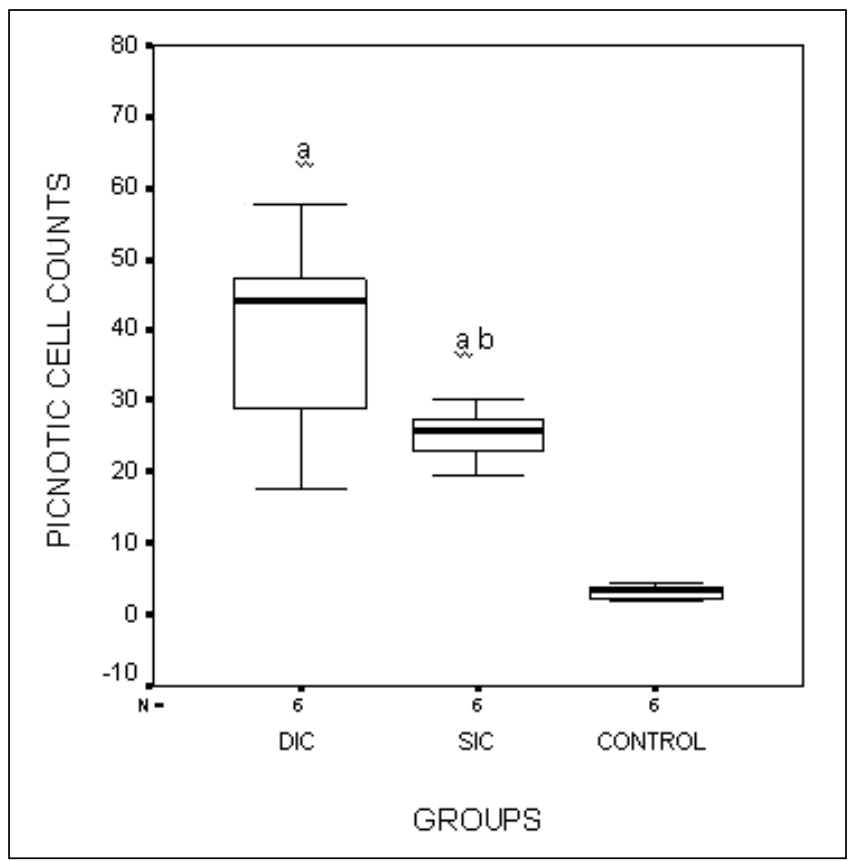

Figure 3: Hippocampal picnotic neuronal cell counts of the groups. DIC = dexmedetomidine intracisternal; $\mathbf{S I C}=$ saline intracisternal, $\mathbf{a}=$ significant difference from the CONTROL group; $\mathbf{b}=$ significant difference from the DIC group. disappearance of typical cellular arrangement, irregularities of intercellular organization, cellular swelling, intracellular vacuoles, and shrinkage of nuclei (Figure 4). The number of excessively degenerated picnotic neurons was especially more in the hippocampal CA3 and DG regions than in the CA1 and $C A 2$ regions.

The histopathological findings were less severe in the SIC group than in the DIC group (Figure 5). The degenerated neuronal cell counts and the degree of degeneration, irregularities of intercellular organizations in the SIC group were significantly less than in the DIC group. When compared with the DIC group, the distribution of the degenerated neuronal cells in the hippocampal regions were more homogenous in the SIC and CONTROL groups. Perivascular edema was observed neither in the $\mathrm{SCl}$ group, nor in the CONTROL group. However, when compared with the CONTROL group, capillary stasis in some of the capillary vessels and minimal edema in some areas of neuropil were observed in the $\mathrm{SCl}$ group (Figure 5, 6).

\section{DISCUSSION}

In order to provide ideal analgesia and anesthesia by neuroaxial route and to lessen the adverse side effects of used local anesthetics, many drugs such as opioids, benzodiazepines, magnesium, ketamine, clonidine have been used as adjuvant $a_{2}$-adrenoceptor agonists have antinociceptive effects which are in part mediated by action on spinal $a_{2}$-adrenoceptors $(13,25)$. Alpha ${ }_{2}$-adrenoceptor agonists have been used in association with local anesthetics to increase the duration of spinal anesthesia. Intrathecal or epidural administration of clonidine prolongs motor blockade induced by local anaesthetics $(13,25)$. Since the affinity of dexmedetomidine to $\mathrm{a}_{2}$-adrenoceptors is eight times greater than clonidine, it

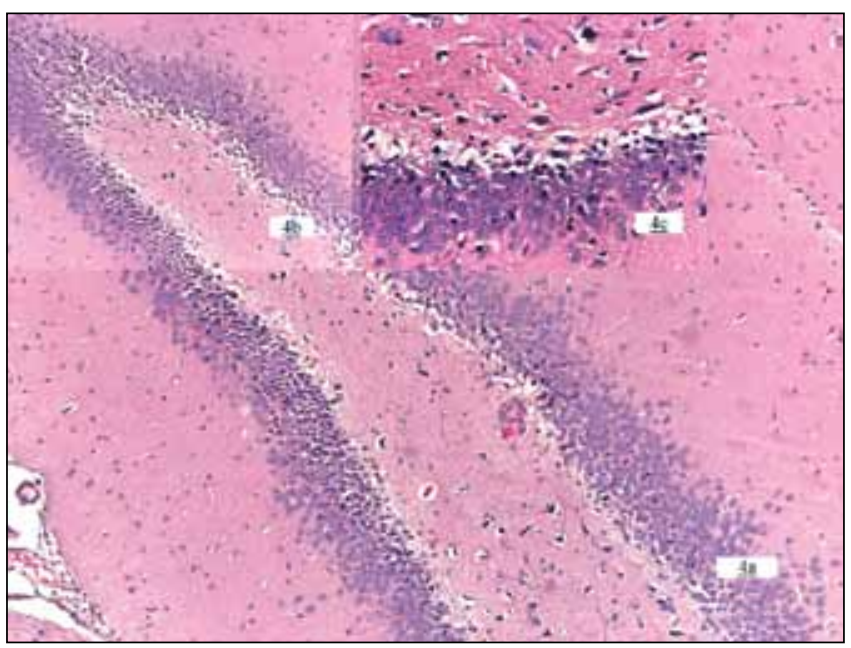

Figure 4: Histopathological specimen of the DIC group demonstrating severe edema both at the neuropil and perivascular area. There were significant capillary stasis and perivascular edema, disappearance of typical cellular arrangement, irregularities of intercellular organization, cellular swelling, intracellular vacuoles, shrinkage of nuclei. (A, H\&E X 200); (B, H\&E X 100); (C, irregularities in the borders of nuclei and homogenization of cytoplasm, H\&E X 400). 


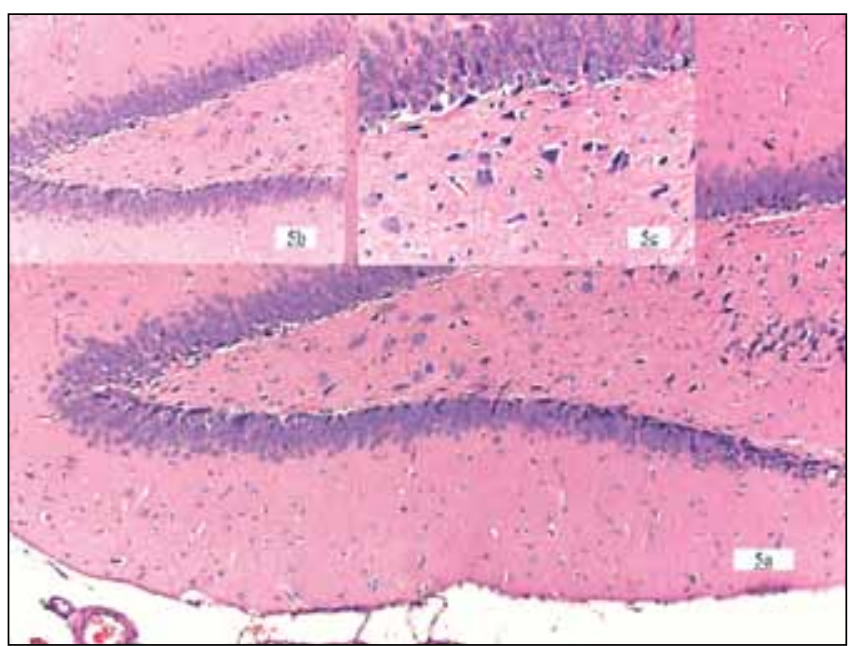

Figure 5: Histopathological specimen of the SIC group. The degenerated neuronal cell counts and the degree of degeneration, irregularities of intercellular organizations in the SIC group were significantly less than in the DIC group. (A, H\&E X 200); (B, H\&E $X$ 100); (C, irregularities and disappearance of some nuclei with homogenization in the cytoplasm, there was no edema either at the neuropil and perivascular area, H\&E X 400).

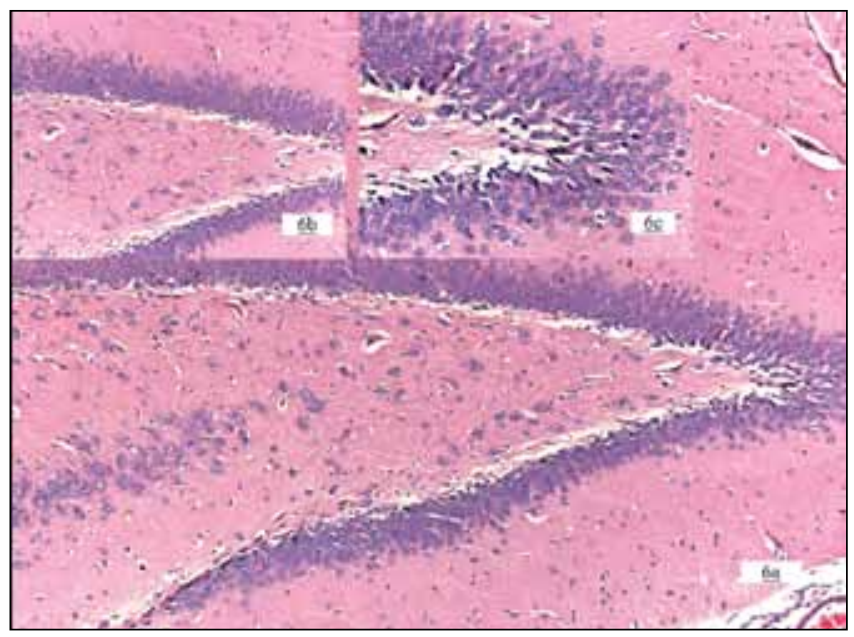

Figure 6: Histopathological specimen of the CONTROL group demonstrating normal intercellular arrangements of neurons in the dentate gyrus sector of the hippocampus, there was no edema either at the neuropil and perivascular area. (A, H\&E X 200); (B, H\&E X 100); (C, H\&E X 400).

is expected that dexmedetomidine could be advantageous in regional anaesthesia $(13,18,25)$. Additionally, it has been reported that dexmedetomidine added to local anesthetics in intravenous regional anesthesia improved the quality of anaesthesia $(5,20)$ and it could partially prevent neuronal damage in some models of ischemia-induced brain injury $(8,9,15-17)$. On the other hand, Konakci et al. reported that dexmedetomidine produced moderate or severe demyelinization of myelin sheats in the white matter of spinal cord in rabbit, when it was administered by the epidural route (14). Because dexmedetomidine is a highly lipo- soluble anesthetic agent, it can easily pass the blood-brain barrier when it is administered into the cerebrospinal fluid intrathecally. In this study, we aimed to investigate the possible toxic effects of dexmedetomidine on cerebral neurons when it was administered centrally into the cerebrospinal fluid by intracisternal route.

In this study, we used the lowest dose of dexmedetomidine (total dose $9 \mu \mathrm{g} / \mathrm{kg}$ ) which is known for its neuroprotective effects by previous studies without any serious systemic adverse side effects $(24,25)$. As it is possible to see the free cerebrospinal fluid flow and due to the easiness of technique, we preferred to administer the agents used in the study into cisterna magna by an injection from posterior craniocervical junction of the rats. Due to the fact that cerebrospinal fluid pressure of rat is very low and aspiration with using negative pressure might be harmful, we did not aspirate any cerebrospinal fluid before the administration of intracisternal drug. However, it was thought that the administered $0.1 \mathrm{ml}$ additional volume within one minute might produce harmful effect on neuronal structures by increasing cerebrospinal fluid pressure. The $\mathrm{SCl}$ group which was $0.1 \mathrm{ml} 0.9 \% \mathrm{NaCl}$ given within one minute by intracisternal route was added to the study for the observation of this possible additional harmful effect.

Kuhmonen et al. reported in their study that there were differences in the number of surviving neurons between the various hippocampal subfields after the dexmedetomidine treatment and this condition might be related to differences in their anatomic connections. They explained these regional differences by the relative distribution and terminal fields of noradrenergic fibers within the different subfields of the hippocampus (16). The noradrenergic afferents arising from the locus cerulous form a dense network within the hilus of the DG and in the stratum lucidum of the CA3 area (26). However, the noradrenergic input to the CA1 subfield is less extensive and terminates largely in the stratum lacunosum moleculare. Therefore, they concluded that any therapeutic treatment that targets noradrenergic systems would be more potent in the hilus and in the CA3 subfield than in the CA1 region of the hippocampus. Hence, the picnotic neuronal cell counts were made in the hippocampal DG region in this study.

In the DIC group, the mean value of the number of the picnotic neuronal cells in the hippocampal DG region was significantly higher than in the SIC and the CONTROL groups. When compared with the DIC group, the distribution of the degenerated neuronal cells in the hippocampal regions were more homogenous in the SIC and CONTROL groups. To be compatible with the study reported by Kuhmonen et al., the histopathologic changes were more severe in the hippocampal CA3 and DG regions than in the CA1 and CA2 regions in the DIC group. This result may be explained by the presence of a dense noradrenergic input in the DG and CA3 regions of hippocampus (26).

Adrenergic receptors are found on cerebral vessels of all sizes throughout the brain (24), supporting the possibility of a direct vascular mechanism for the cerebral blood flow 
effects of centrally administered $a_{2^{-}}$adrenergic agonists. It was reported in an in vivo experimental study that topical application of dexmedetomidine had vasoconstrictor effects both on cerebral pial arterial and venous vessels (11). Since this vasoconstrictive effect could be blocked by $a_{2}$-adrenergic antagonist agent yohimbine, the dexmedetomidine-induced vasoconstriction was attributed to the activation of the vascular $a_{2}$ - adrenergic receptors. Additionally, it was shown in another experimental study that, ventricular-coeternal perfusion of dexmedetomidine resulted in widespread cerebral blood flow reduction either normoxic or hypoxic conditions (19). Konakci et al. were shown in their study that dexmedetomidine produced the moderate or severe demyelinization of myelin sheaths in the white matter of spinal cord, when it was administered by the epidural route. They suggested that this effect could be related to vasoconstriction of the medullary spinal vessels (14). However, they did not evaluate the possible toxic effects of dexmedetomidine on cerebral neuronal cells when it was administered by epidural route. lida et al. reported that cerebral vessels were more sensitive to the $a_{2}$-adrenergic stimulation than the spinal counterparts (10). Hence, we thought that the toxic effect of centrally administered dexmedetomidine into the cerebrospinal fluid by intracisternal route on cerebral neurons might be resulted from a direct vasoconstrictive effect mediated by cerebral vascular $\mathrm{a}_{2}$-adrenergic receptors.

The picnotic neuronal cell count in the $\mathrm{SCl}$ group was significantly more than the CONTROL group. This situation was contributed to the produced increase in the cerebrospinal fluid pressure resulted from the additional injection of $0.1 \mathrm{ml}$ volume of normal saline into the cerebrospinal fluid.

As a biochemical indicator of cerebral cellular damage, both the mean value of the brain tissue LPO levels and the mean value of the plasma LPO levels was significantly higher in the DIC group than the SIC and CONTROL groups. These biochemical results were compatible with the histopathological results of this study.

Another explanation for the neurotoxic effect of centrally administered dexmedetomidine can be made by the low $\mathrm{pH}$ value of the agent. Dexmedetomidine is supplied as an isotonic solution with a $\mathrm{pH}$ of 4.5-7. However, it is known that, clonidine, which has a similar $\mathrm{pH}$ of 5-7 does not exert any neurotoxic side effects $(28,29)$. Additionally, since the solution is preservative-free and contains no additives or chemical stabilizer, we did not think that the neurotoxic effect of centrally administered dexmedetomidine could be related to additives, chemical stabilizers or its low $\mathrm{pH}$.

This prospective experimental study has some pitfalls. Firstly, this study could not be supported by immunohistochemical, and electron microscopic findings. Secondly, because the study was designed as a short-term, preliminary study, and the main aim the study was to investigate whether dexmedetomidine had a toxic effect on cerebral neurons when it was administered centrally into the cerebrospinal fluid by histopathological and biochemical evaluations all animals were decapitated after 24 hours from the intracisternal drug administration. Although it is known that the hippocampus plays important roles in the consolidation of information from short-term memory to long-term memory and spatial navigation and there were animal studies which have been shown that an intact hippocampus is required for initial learning and long-term retention of some spatial memory tasks (30-33), we did not perform the tests related with hippocampal functions which were required more longer study and evaluation period than 24 hours. Additionally, this study did not contain observations of neurologic outcome and of functional outcome data and histopathological and biochemical evaluations occurring in the long run.

In conclusion, dexmedetomidine had a toxic effect on cerebral neurons when it was administered centrally into the cerebrospinal fluid by the intracisternal route. Although the effect mechanism and/or mechanisms are not clear, this neurotoxic effect of dexmedetomidine can be attributed to a direct vasoconstrictive effect mediated by cerebral vascular $\mathrm{a}_{2}$-adrenergic receptors. In order to administer this highly lipo-soluble, selective $a_{2}$-adrenergic agonist by intrathecal route as a safe adjuvant agent, further studies using advanced pathologic investigations are required.

\section{REFERENCES}

1. Asano T, Dohi S, Ohta S, Shimonaka H, lida H: Antinociception by epidural and systemic alpha 2-adrenoceptor agonists and their binding affinity in rat spinal cord and brain. Anesth Analg 90: 400-407, 2000

2. Calasans-Maia JA,Zapata-Sudo G, Sudo RT:Dexmedetomidine prolongs spinal anesthesia induced by levobupivacaine $0.5 \%$ in guinea-pigs. J Pharm Pharmacol 57: 1415-1420, 2005

3. Ebert TJ, Hall JE, Barney JA, Uhrich TD, Colinco MD: The effects of increasing plasma concentrations of dexmedetomidine in humans. Anesthesiology 93: 382-394, 2000

4. Eser O, Fidan H, Sahin O, Cosar M, Yaman M, Mollaoglu $H$, Buyukbas S: The influence of dexmedetomidine in ischemic rat hippocampus. Brain Research 1218: 250-256, 2008

5. Esmaoglu A, Mizrak A, Akin A, Turk Y, Boyaci A: Addition of dexmedetomidine to lidocaine for intravenous regional anesthesia. Eur J Anaesthesiol 22: 447-451, 2005

6. Gordh TE, Ekman S, Lagerstedt AS: Evaluation of possible spinal neurotoxicity of clonidine. Ups J Med Sci 89: 266-273, 1984

7. Gordh TE, Post C, Olsson Y: Evaluation of subarachnoid clonidine, guanfacine, and a substance P-antagonist on rat spinal cord and nerve roots. Anesth Analg 65:1303-1311, 1986

8. Goyagi T, Nishikawa T, Tobe Y, Masaki Y: The combined neuroprotective effects of lidocaine and dexmedetomidine after transient forebrain ischemia in rats. Acta Anaesthesiol Scand 53: 1176-1183, 2009 
9. Hoffman WE, Kochs E, Werner C, Thomas C, Albrecht RF: Dexmedetomidine improves neurologic outcome from incomplete ischemia in the rat. Reversal by the alpha 2-adrenergic antagonist atipamezol. Anesthesiology 75: 328-232, 1991

10. lida $H$, Orate $H$, lida $M$, Watanabe $Y$, Dohi S: Direct effects of alpha 1- and alpha 2-adrenergic agonists on spinal and cerebral pial vessels in dogs. Anesthesiology 91:479-485, 1999

11. Ishiyama $T$, Dohi $S$, lada $H$, Watanabe $Y$, Shimonaka $H$ : Mechanisms of dexmedetomidine-induced cerebrovascular effects in canine in vivo experiments. Anesth Analg 81: 1208-1215, 1995

12. Jolkkonen J, Puurunen K, Koistinaho J, et al: Neuroprotection by the alpha 2- adrenoreceptor agonist, dexmedetomidine, in the rat focal cerebral ischemia. Eur J Pharmacol 372: 31-36, 1999

13. Kingery WS, Davies MF, Maze M: Molecular mechanisms for analgesic properties of alpha-2 agonists. Prog Pain Res Manage 9: 275-304, 1997

14. Konakci S, Adanir T, Yilmaz G, Rezanko T: The efficacy and neurotoxicity of dexmedetomidine administered via the epidural route. Eur J Anaesthesiol 25: 403-409, 2008

15. Kuhmonen J, Haapalinna A, Sivenius J: Effects of dexmedetomidine after transient and permanent occlusion of the middle cerebral artery in rat. J Neural Transm 108: 261-271, 2001

16. Kuhmonen J, Pokorný J, Miettinen R, Haapalinna A, Jolkkonen $J$, Riekkinen P Sr, Sivenius J: Neuroprotective effects of dexmedetomidine in gerbil hippocampus after transient global ischemia. Anesthesiology 87: 371-377, 1997

17. Maier C, Steinberg GK, Sun GH, Zhi GT, Maze M: Neuroprotection by the a2-adrenoreceptor agonist dexmedetomidine in a focal model of cerebral ischemia. Anesthesiology 79: 306-312, 1993

18. Maze $M$, Tranquilli W: Alpha-2 adrenoceptor agonists. Defining the role in clinical anesthesia. Anesthesiology 74 : 581-605, 1991

19. McPherson RW, Koehler RC, Kirsch JR, Traystman RJ: Intraventricular dexmedetomidine decreases cerebral blood flow during normoxia and hypoxia in dogs. Anesth Analg 84: 139-1347, 1997

20. Memis D, Turan A, Karamanlioglu B, Pamukcu Z, Kurt I: Adding dexmedetomidine to lidocaine for intravenous regional anesthesia. Anesth Analg 98: 835-840, 2004

21. Mihara M, Uchiyama M: Determination of malonaldehyde precursor in tissues by thiobarbituric acid test. Anal Biochem 86: 271-278, 1977
22. Ohkawa H, Ohishi N, Yagi K: Assay for lipid peroxides in animal tissues by thiobarbituric acid reaction. Anal Biochem 95: 351-358, 1979

23. Otsuguro K, Yasutake S, Ohta T, Ito S: Effects of opioid receptor and alpha 2- adrenoceptor agonists on slow ventral root potentials and on capsaicin and formalin tests in neonatal rats. Brain Res Dev Brain Res 158: 50-58, 2005

24. Peroutka SJ, Moskowitz MA, Reinhard JF Jr, Synder SH: Neurotransmitter receptor binding in bovine cerebral microvessels. Science 208: 610-612, 1980

25. Pertovaara A: Antinociception induced by alpha-2 adrenoceptor agonists, with special emphasis on dexmedetomidine studies. Prog Neurobiol 40: 691-709, 1993

26. Swanson LW, Kohler C, Bjorklund A: The limbic region I. The septohippocampal system. Handbook of Chemical Neuroanatomy. Vol 5. In: Swanson LW, Hoktelt T, Bjorklund A ed, Integrated Systems of the CNS. Part I. Amsterdam, Elsevier Science Publishers, 1987:125-277

27. Wade CR, Van Rij AM: Plasma thiobarbituric acid reactivity: Reaction conditions and the role of iron, antioxidants and lipid peroxy radicals on the quantitation of plasma lipid peroxides. Life Sciences 43: 1085-1093, 1998

28. Wahlander S, Frumento RJ, Wagener G, Saldana-Ferretti B, Joshi RR, Playford HR, Sladen RN: A prospective, double-blind, randomised, placebo-controlled study of dexmedetomidine as an adjuvant to epidural analgesia after thoracic surgery. J Cardiothorac Vasc Anesth 19: 630-635, 2005

29. Xu M, Kontinent VK, Kalso E: Effects of radolmidine, a novel alpha 2-adrenergic agonist compared with dexmedetomidine in different pain models in the rat. Anesthesiology 93: 473-481, 2000

30. Squire LR: Memory and the hippocampus: A synthesis from findings with rats, monkeys, and humans. Psych Rev 99: 195-231, 1992

31. Morris RG, Garrud P, Rawlins JN, O'Keefe J: Place navigation impaired in rats with hippocampal lesions. Nature 297: 681-683, 1982

32. Sutherland RJ, Weisend MP, Mumby D, Astur RS, Hanlon FM, Koerner A, Thomas MJ, Wu Y, Moses SN, Cole C, Hamilton DA, Hoesing JM: Retrograde amnesia after hippocampal damage: Recent vs. remote memories in two tasks. Hippocampus 11 : 27-42, 2001

33. Clark RE, Broadbent NJ, Squire LR: Hippocampus and remote spatial memory in rats. Hippocampus 15: 260-272, 2005 